\author{
Marquette University \\ e-Publications@Marquette
}

College of Education Faculty Research and

Publications

Education, College of

2008

\title{
Student Satisfaction and Performance in an Online Teacher Certification Program
}

Heidi Schweizer

Marquette University, heidi.schweizer@marquette.edu

Carrianne H. Hayslett

Marquette University

Sharon Katherine Kayne Chaplock

Marquette University

Follow this and additional works at: https://epublications.marquette.edu/edu_fac

Part of the Education Commons

\section{Recommended Citation}

Schweizer, Heidi; Hayslett, Carrianne H.; and Kayne Chaplock, Sharon Katherine, "Student Satisfaction and Performance in an Online Teacher Certification Program" (2008). College of Education Faculty Research and Publications. 94.

https://epublications.marquette.edu/edu_fac/94 


\title{
Student Satisfaction and Performance in an Online Teacher Certification Program
}

\author{
Authors: Heidi Schweizer, Carrianne Hayslett, \& Sharon Chaplock
}

Distance education continues to expand, from a reported 1.6 million students enrolled in distance education courses in 1998 (NCES, 1999) to 3.2 million in 2005 (Sloan Consortium, 2006). As online education has come to dominate all types of courses taught at a distance, and constitutes a greater proportion of overall enrollment in higher education, researchers have increasingly investigated a host of questions regarding its viability as an alternative to traditional on-campus education. Consistently, this research has found online education equals or surpasses on-campus instruction in terms of student learning, student perceptions, and student satisfaction (Neuhauser, 2002; Thirunanrayanan \& Perez-Prado, 2002; Russell, 2001; Arbaugh, 2000), thus supporting its viability and continued development.

Online delivery of teacher education courses is well established, with practicing teachers taking courses online for faculty development, graduate degrees, and professional specializations, such as special education and the teaching of reading (Watson, 2006; Qian \& Tao, 2005; Glenn \& Lozar, 2001; Saunders, 2001; Turbill, 2001). Caywood and Duckett (2003) and Neuhauser (2002) find online delivery effective for teacher education, with opportunities for online in-service programs proliferating. However, teacher education programs have been slower to provide online courses to pre-service teachers and slower still to develop teacher certification programs with coursework delivered entirely at a distance. This is despite online teacher preparation being a major funding area of the Preparing Tomorrow's Teachers to Use Technology (PT3) grant program (U.S. Department of Education, 2005). Zirkle (2002) suggests that this lack of progress may be largely due to concerns about providing:

- appropriate practical experiences to pre-service teachers to accompany their online "classroom" learning,

- appropriate interpersonal interaction,

- sufficient opportunity to assess the progress of pre-service teachers, and

- opportunities for instructors to model particular teaching strategies.

Practicing teachers who are earning graduate degrees, involved in professional development, or seeking further specialization have classroom experiences that provide support 1 Schweizer, Hayslett, \& Chaplock 
and context for the skills and knowledge they acquire in online courses. In contrast, pre-service teachers seeking certification do not have commensurate practical experiences. To make the online experience similar to the experiences provided students in on-campus certification programs, a clinical component is needed to compensate for pre-service teachers' limited classroom exposure.

The few online teacher certification programs currently available have adopted unique structures to provide practical experiences to accompany pre-service certification instruction. NCTEACH ONLINE, for instance, requires students beginning the program to attend an on-campus "summer institute." After completing the summer program, each participant is granted a provisional teaching license and begins his/her first year of teaching, during which s/he completes six online courses to earn a clear credential (Simmons \& Melbane, 2005). Alternatively, Western Governors University, a virtual university delivering courses online, developed online undergraduate and post-baccalaureate teacher certification programs in 2003 in which pre-service teachers meet required competencies through previous experience and online courses, then complete 12-week to year-long practice teaching placements (Carnevale, 2003; U.S. Department of Education, 2003). Neither of these programs provides a traditional ("nonalternative") post-baccalaureate certification program online.

The research examining individual courses taken by pre-service teachers supports the effectiveness of online delivery for teacher certification courses. Skylar, Higgins, Boone, and Jones (2005), for instance, in comparing traditional instruction, online instruction, and "class-in-a-box" CD-ROMs found all three environments equally effective instructionally. Steinweg, Davis, and Thomson (2005) found no significant difference in face-to-face and online instruction as measured by pre- and post-tests and class projects scores. Despite the support this research provides, these studies do not sufficiently illuminate the effectiveness of entire pre-service certification programs offered online in developing professionals prepared for the varied and complex tasks of teaching (Institute for Higher Education Policy, 1999). There are to date no studies focusing on teacher certification programs delivered entirely online, leaving concerns about the effectiveness of such programs unaddressed.

Further, there are methodological issues with existing studies, as they generally compare students in online and face-to-face settings without consideration of the challenges such comparisons create. For instance, to appropriately compare students in online and on-campus courses, researchers must employ random assignment (usually an impossibility) or other controls for self-selection and group differences, which is rarely done. Often, there are also measurement 
inconsistencies, such as comparing proctored, face-to-face exams with unproctored, online assessment (Poirer \& Feldman, 2004), which fall short of providing parallel data for comparison (Institute for Higher Education Policy, 1999).

In light of these research gaps, this study investigated the degree to which an online teacher certification program prepares students for classroom teaching by studying a cohort of students, treated as a single case study. Student achievement is examined using standards of teacher effectiveness, rather than trying to compare online and on-campus instructional delivery. At base, the question is not how effective online pre-service teacher training is as compared to on campus pre-service teacher training, but how well online pre-service teacher training prepares teachers for the responsibilities and challenges of teaching. Recent trends in employing standards-based requirements for obtaining teaching licensure assist in answering this question.

Traditionally, states have overseen teacher preparation programs by verifying candidates' course or credit completion in approved programs. The result was often a vast array of rigor, quality, and effectiveness among teacher preparation programs as each program developed its own courses, often with individual instructors developing their own course assessments. In 1990, the Interstate New Teacher Assessment and Support Consortium (INTASC) with a 17-state task force created assessment standards in an effort to develop "a coherent approach to educating and licensing teachers based upon shared views among the states and within the profession of what constitutes professional teaching" (Council of Chief State School Officers, 2006). The work of INTASC and the need for a restructuring of teacher education and licensure to one in which teachers demonstrate standards-and performance-based competencies prompted state departments of public instruction to develop 10 standards for assessing teacher licensure candidates (INTASC, 1992). These standards map to a number of assessments this study analyzes: student course grades, their perceptions of readiness to teach before and after student teaching, their student teaching evaluations, their scores on state mandated standardized tests, and a limited number of evaluations by the administrators following three candidates' completion of their induction year.

\section{Design and Methodology}

\section{The Program}

The post baccalaureate teacher certification program examined in this study was developed by a Wisconsin university and delivered entirely online. It accepted its first cohort in the summer of 2004. Candidates accepted to the program meet rigorous admissions standards,

3 Schweizer, Hayslett, \& Chaplock 
including acceptable PRAXIS 1 comprehensive scores (state-required test for basic reading, math and writing skills), submission of official transcripts verifying an earned bachelor's degree with a minimum grade point of 2.75 overall and a 3.0 in the content area in which certification is desired, a personal statement and interview, and three letters of recommendation. After this demanding application process, candidates accepted to the program were required to successfully complete seven online courses over four semesters. Course content included foundational knowledge and skills in learning theories and curriculum foundations, instructional methods, child development, technology integration, and curriculum diversification. Course instructors maintained a significant presence in the online courses by engaging and interacting with students in required weekly asynchronous discussions. Faculty responded promptly to weekly written assignments with suggestions for improvement and questions for further deliberation. Regularly required journaling activities were used to help students connect new knowledge and skills to past experiences. Finally, each course required the student to submit an end-of-course project (unit plan, student assessment with rubrics, classroom management plan, or case study, for example) as evidence of being able to apply course concepts and knowledge to the act of teaching. A total of 100 hours of clinical field experience was integrated into each of the required courses, and a mandatory semester of student teaching served as a capstone experience.

As Wisconsin was an INTASC task force state, the Wisconsin Department of Public Instruction adopted a standards-based certification process. To receive a teaching license, candidates must demonstrate proficient performance in the knowledge, skills, and dispositions contained in the state standards for teacher development and licensure (Wisconsin Department of Public Instruction, 2006). All assessments of teacher candidates in this study were directly linked to the standards and included: (a) students' competence on the standards-based critical tasks completed as part of their coursework and measured by final course grades; (b) their standards-based student teaching evaluations; and (c) the initial evaluations of their first year of service by school administrators based on the 10 standards.

\section{The Questions}

To investigate the degree to which pre-service teachers were prepared to teach, we used a case study approach employing multiple methods (surveys and interviews) and multiple data sources (course evaluations, student assessments, grades, and test scores) to create a detailed examination of the online teacher certification program offered over a three-year period (Johnson \& Christensen, 2004). Since case study research is "simply research that provides a detailed 
account and analysis of one or more cases" (Johnson \& Christensen, 2004), studying the online certification program as a single case, bounded by time, participants, and a specified curriculum, provided an opportunity to explore the nuances of the interrelated elements at work in becoming a teacher through an online preparation program. The central questions guiding our research were:

- To what extent can an online post baccalaureate teacher certification program adequately prepare pre-service teachers to teach? What is the quality of the graduates' teaching?

- What are the benefits and challenges in offering such a program? Who are the people who are attracted to and complete an online teacher certification program?

\section{Data sources}

Primary data were obtained from a variety of sources. Data related to the perceived effectiveness of the online course environment and satisfaction with the course design and instruction were collected through course evaluations and other student surveys. The course evaluations were administered at the end of each of the seven required courses. Additionally pre-program and post-program surveys were completed by students before and after student teaching as well as at the end of the first year of teaching. The surveys measured student perceptions as to how prepared they felt they were to teach in relation to the Wisconsin State Teaching Standards. Student mastery of subject matter content and pedagogical knowledge was examined via scores on the PRAXIS 2 test and course grades. Passing scores on the PRAXIS 2 test, which is a post-coursework, pre-certification examination of content knowledge, provided evidence of preparedness to teach in specific subject areas. The final course grades reflected student progress on specific critical tasks embedded in each course. For example, in the Using Technology for Instruction and Assessment course, students were required to complete a WebQuest and an Authentic Learning Project Plan, both demonstrating evidence of planning for the integration of technology into student learning activities.

Standard forms used to evaluate the student teaching experience were collected from each university supervisor and each cooperating teacher. Again, the items on the student teacher evaluation were directly linked to the Wisconsin State Standards, as was an evaluation form sent to the principals of the schools where graduates of the program completed their induction year of teaching.

Additionally, in order to capture insights and perceptions on student's motivations for applying to an online certification program, phone interviews were arranged for 15 students during 
the fall semester of the project's final year. The phone interviews focused on reasons students were attracted to the program and whether online delivery was a significant factor in their selecting the program.

Finally, demographic data (age, race, gender, hometown, and previous work experience) were collected from all candidates to allow for more advanced analysis of their participation in the program.

\section{Data considerations}

Thirty-three students enrolled in the program, with 19 completing certification in six different content areas. Of the 14 who did not complete the program, 10 students dropped the program after completing part of the coursework, and four students completed the coursework, but for various reasons (employment conflicts or failure to pass the state required PRAXIS 2 exam, for instance) did not begin the required semester of student teaching. For the purpose of this study, group data on the initial 33 candidates will be presented to detail demographic profiles of the students starting the program. In addition, demographic data on the 14 who did not complete the program will be discussed. All remaining data were collected from the 19 completing the certification program.

Because one of the researchers also served as an instructor for one of the online courses, a research assistant collected all surveys and conducted all interviews. This assistant assigned pseudonyms to each survey and interview transcription to ensure student anonymity and minimize research bias.

\section{Analysis}

If the online certification program and its performance-based assessments have appropriately prepared teachers for classroom placements, their work during the program should be highly related to the evaluations of teaching they receive during their student teaching experience and their first year of teaching. To ascertain ways in which the online teacher certification program adequately prepared pre-service teachers for their classroom experiences, we analyzed the measures of student perception regarding preparedness for teaching, their student teaching evaluation scores submitted by both their cooperating teacher and university supervisor, and their induction year evaluations. Pre-program and post-program survey scores were compared using simple tables and, where appropriate, overall averages were calculated. Teaching evaluations scores were also compiled into tables with columns for each teaching standard. Principal evaluations were assessed by at least two researchers with an eye for 
evidence of either satisfactory or unsatisfactory performance. In addition, course grades and PRAXIS 2 exam scores were used to investigate the degree to which students mastered both subject-area and pedagogical-knowledge content. To better understand the challenges and opportunities this online certification program provided, interviews with students were transcribed and color-coded for emerging themes. This, coupled with demographic data, helped to complete a detailed description of the types of students attracted to and completing an online program as well as those students who failed to complete: specifically their preparedness for classroom teaching, the depth of their content knowledge, breadth of life experiences brought to the program, and degree of diversity in age, gender, and race.

\section{Results}

\section{Demographics}

Analysis of demographic data revealed that the typical student enrolled in the program was female, middle aged, Caucasian, and living within Wisconsin. Of the 33 students beginning the program, 20 were female and 13 male averaging 37.6 years of age (range $22-54$ years). All candidates were Caucasian except for one African-American. Sixteen candidates resided within 15 miles of the university campus, with 14 living elsewhere in the state, two living outside the state, and one living outside the country, in Kuwait. The major areas of certification included nine candidates in science, ten in social studies, three in business, five in math, three in English, and one each in theater, Spanish, and journalism. Equally as diverse as the areas in which students sought certification were the positions they held while completing the online program: seven were homemakers, one of whom was an Army veteran; six were teaching with emergency teaching licenses; four had just completed an undergraduate degree; four were employed in institutions of higher education, one as a parking attendant, two as lab technicians, and one as a research librarian; one was an active member of the Air Force, and 11 came from corporate and self-employed business settings, including marketing, information technology, engineering, and entertainment/ recreation.

\section{Attrition}

The fact that $42 \%$ of the original group of students (14 out of 33 ) did not complete the program prompted investigation. Attrition in online learning programs is a significant issue for administrative and academic reasons. First, attrition information can guide program planning, providing information about the cost effectiveness of online programs as compared to their on-campus counterparts. Second, it can provide information about the instructional effectiveness 
of courses and guidance for increasing student engagement and learning (Tyler-Smith, 2006). The literature reports various figures for attrition in online learning, from Flood's (2002) report of rates up to $80 \%$ to Diaz's (2002) more conservative $20-50 \%$ rate to Carr's (2000) more contextualized $10-20 \%$ above an institution's attrition rate for on-campus offerings.

Much of the dialogue about attrition rates in postsecondary education has developed out of Tinto's $(1975,1987)$ model of attrition in higher education that connects attrition with academic non-success, positing that students' departure decisions from higher education are based on a dynamic interaction between several factors: student characteristics (including prior schools, skills, and abilities, and goals and intentions), academic integration (academic performance and experiences with faculty and staff), and social integration (extracurricular involvement and peer-group interactions). Based on this model, adult learners may seem more adaptable and better suited for academic success, particularly given their wealth of academic and personal prior experience, the propensity for them to have well-formed goals, and the potential for them to bring these factors to bear on their academic and social integration. Yet, more recent work has called into question the applicability of Tinto's model to adult learners (Bean \& Metzner, 1985, McCubbin, 2003; Tyler-Smith, 2006) and online education (Meyer, Bruwelheidi, \& Poulin, 2006; Rovai, 2002). Kember (1989) revised Tinto's model to better account for the circumstances of adult learners, including integrating "part time, off campus study with family, work and social commitments" (p. 294). Boyles (2004) broadened this model to more generally account for a range of background (i.e., maturity and previous experience), environmental (i.e., family, work, and social commitments), and academic factors (i.e., previous academic track record) to better encompass adult learners. Yet, in an attempt to better account for the complexity of learners' characteristics and experiences, these models are of limited assistance in dealing with the issue of attrition in online learning (Tyler-Smith, 2006).

Diaz (2002), in particular, suggests that the attrition rate of online programs may bear re-examination. Previous conceptions of attrition have defined it as "academic nonsuccess." Diaz proposes that perhaps many of those who drop online classes do so because it is "the right thing to do" if the student evaluates his/her circumstances to be in conflict with appropriate learning and academic success in the class. "Thus, by dropping the class, they may be making a mature, well-informed decision that is consistent with a learner with significant academic and life experience. This explanation would be consistent with their demographics while calling into question the idea that these students are academically unsuccessful or possess inferior academic abilities" (Diaz, 2002, \10). Our analysis reveals individual circumstances as the most cited 
reason for leaving the program, supporting Diaz's (2002) contention, yet we suggest further research to investigate the ways in which online programs largely intended to provide flexible and convenient learning options for nontraditional students and adult learners might be designed in ways that assist these students in negotiating their multiple responsibilities. It is this gulf between theory and practice that prompts Diaz (2002) to suggest that perhaps the best way to examine attrition in online learning is to ask learners themselves why they leave online programs. This suggestion paralleled our response to the attrition rate in our program.

A follow-up email to the 14 non-completers revealed that (a) five students (including two from outside Wisconsin) were unable to complete the program due to job responsibilities that interfered with completing the student teaching and clinical hours requirements, (b) three had family emergencies for which they assumed major caregiving responsibilities, (c) three (including one from outside Wisconsin) were unable to either find a location to take the required PRAXIS 2 exam (two) or were unable to pass it (one), and (d) three failed to respond to the follow-up email. Though it appears from the data that distance from campus is less a reason for non-completion than job and family responsibilities interfering with the program requirements, the specific challenges faced by students seeking certification online across state lines bears further research.

A demographic profile of those who did not complete the program reveals no evident trend in occupation, age, or gender. Seven males and seven females beginning the program did not complete it. Six students within the age range of 21-32 years were non-completers, while six in the range of 33-43 years and two in the 45-54 age categories were unsuccessful in earning a teaching license. Of the six employment categories describing the occupations the students held when starting the program, four of the non-completers were homemakers, five worked in the business sector, two held emergency teaching licenses and were teaching, and one each was employed by either a university or college, was active in the military, or was a recent college graduate.

More significant, perhaps, were the data on certification area, ethnicity, and geography. Of the five students beginning the program to obtain certification to teach math, all five failed to complete the program. Of the five students, four were women, but all other demographics were equally distributed across the five students. One of the students seeking math certification failed to pass the Praxis 2 exam, while the other four dropped much earlier in the program, failing to complete the required sequence of courses. Additional investigation is needed to fully explain why all five candidates dropped, particularly in light of the high need for qualified math teachers in 
urban high school classrooms (Darling-Hammond, 2007).

Given the intention of this program to attract diverse applicants and the fact that only one non-white student applied and was accepted to the program, this study does little to illuminate the role of online certification in developing teachers from diverse backgrounds. Several factors, particular to this specific program and related to online teacher certification in general, may be evident in the racial demographics of this program. First, the university providing the program has somewhat limited racial diversity, perhaps making it a less attractive school for diverse applicants to all programs. Second, issues related to the intersection of race and technology may affect an online program's attractiveness to diverse candidates. For many years discourse on the digital divide evident in technology use by race has focused on access issues, while more recent research has focused on use (Howard \& Jones, 2004). Although the percentage of African-American households with computers rose from 11.2 to 23.5 between 1998 and 2000, and the percentage of Latino households with computers rose from 12.6 to 23.6 for the same time period, white households still outpaced them, with 46.1\% owning computers in 2000 (U.S. Department of Commerce, 2000). This notable disparity is further illuminated by a 2000 Pew Foundation study finding $56 \%$ of whites access the Internet on a typical day, as opposed to only $36 \%$ of African Americans (Spooner \& Rainie, 2000). This study further found African Americans more likely to access the Internet for "fun" (such as to shop, listen to music, chat, or access sports information) than whites, who tend access the Internet more for informational and retail purposes. Finally, issues regarding race and teacher certification may affect the attractiveness of teacher certification programs to minority applicants. Shen (1999), for instance, found almost $90 \%$ of the math and science teachers in the Schools and Staffing Survey were white. Although these factors may add context to the lack of racial diversity of this program, they highlight the need for further research as to how the intersection of these issues might affect minority participation in and completion of online teacher certification programs.

None of the students living outside the state completed the program. This is another area of concern, given that a notable feature of providing online delivery of teacher certification is to allow students to learn at a distance. One factor mitigating this concern is that those living out of state who left the program early did so for personal issues and job responsibilities, as opposed to program-related problems or lack of achievement in the program. However, although the program was delivered entirely online, the learning experiences of those living in-state were not completely similar to those living out of state. Those living within a short distance of the university often visited the campus, talked face-to-face with instructors and sometimes met in small groups for projects, 
or just to have a cup of coffee. Whether the opportunity to informally meet face-to-face with candidates contributed to program completion is another area for further investigation.

Examining overall program efficacy is important in establishing online teacher certification as a viable instructional method, but it is also important to consider the ways in which this online certification program might be more effective for some than for others, as these considerations may lead to program policies and practices that better meet the needs of diverse participants. The analysis of data from this program leaves open questions about differential effectiveness_-especially along racial lines, for particular subject areas, and for those seeking certification in states in which they do not reside. Future examination of this question must move beyond employing attrition models and would be well served by asking students what factors caused them to see leaving the program as the best decision, and by also asking them to consider the ways in which the program might have been more accommodating of the multiple responsibilities online students often carry.

\section{Grades}

Course grades (reflecting critical tasks that included lesson plans, reflective journals, case studies, and self video tapes, collected and evaluated throughout the program) demonstrated each candidate's proficiency in the 10 standards. The overall grade point average for the 19 candidates completing the required seven courses was 3.95 on a 4.0 scale. Those completing the program excelled in their coursework. Student teaching assessments also indicate candidate proficiency and are discussed in detail later.

\section{Praxis Scores}

All pre-service teachers in Wisconsin are required to pass a basic math, reading, and writing test (PRAXIS 1) and a subject matter test (PRAXIS 2). A passing score on the PRAXIS 1 exam was required for admission to the program. A passing score on the PRAXIS 2 exam was required prior to student teaching. An analysis of the PRAXIS 1 and PRAXIS 2 scores showed that candidates consistently scored higher than the minimum required score for both tests. For PRAXIS 1, the minimum proficiency scores for reading, math, and writing were 175, 173, and 174 respectively, while students in the online program scored on the average of 183 for reading, 185 for math, and 180 for writing. Although these results cannot be used to show program effectives, it does suggest that a pool of highly qualified candidates was attracted to the program. Similar results were reported for the PRAXIS 2 exam, with all students outscoring the minimum proficiency by $14-32 \%$.

\section{Course evaluations and surveys}

11 Schweizer, Hayslett, \& Chaplock 
Course evaluations, pre-program and post-program student teaching surveys, and post-induction year surveys indicated students generally had a high degree of satisfaction with the program and a sense that the program prepared them for both student teaching and their induction year of teaching. The course evaluations, for which there was a $90 \%$ response rate, consisted of 51 questions asking students to respond on a scale of 1-4 (strongly agree, agree, disagree, and strongly disagree) to topics related to the course management system, instructor effectiveness, course design, technical assistance, and the online learning experience in general. Analysis of the survey reveals:

- $90 \%$ were satisfied with the course they took, with $54 \%$ giving the course a superior rating.

- $89 \%$ were satisfied with the instructor(s), with $62 \%$ giving the instructor a superior rating,

- $94 \%$ found the course assignments useful learning tools.

- $82 \%$ found their learning enhanced by the interaction of the students and instructor.

- $98 \%$ would take another online class.

- $94 \%$ would recommend an online course to their friends.

- $89 \%$ said they put more thought into their comments because the course was online.

- $90 \%$ said their effort was equal to or greater than other courses they had taken.

- $82 \%$ found their learning enhanced by the interaction of the students and instructor.

Pre-program and post-program student teacher surveys, for which eight of the 19 students completing the program responded to both ( $42 \%$ response rate), consisted of 56 questions grouped into 11 categories mirroring the 10 Wisconsin Teaching Standards, plus an additional question related to how well they felt the online program prepared them to teach. Results are shown in Table 1.

Respondents indicated that prior to beginning their student teaching placement they believed that the course materials and student-to-student interaction prepared them well for understanding that children learn differently; course discussions and assignments prepared them well for knowing how children grow; and instructor-to-student interaction was an effective method for evaluating their preparation for teaching. Student-to-student interaction and course discussions were perceived as effective preparation for planning different kinds of lessons. Following their student teaching experience, students believed that the online teacher certification program had actually prepared them more than they originally thought for communicating well and for planning different kinds of lessons. Prior to student teaching they felt that course materials 12 Schweizer, Hayslett, \& Chaplock 
helped them understand that children learn differently. Further, following completion of student teaching, they perceived that the course assignments and student-to-student interactions were the most important course activities preparing them for knowing how to teach. Significantly, the standards addressing knowledge of the subject matter being taught and knowledge about how children grow declined in all course methods areas in their post-student teaching survey responses, which raises the concerns about the effectiveness of the program in these areas. Even though all 19 candidates completing the program met (and often exceeded) the minimum score required for the PRAXIS 2 exam (assessing content knowledge), a disconnect may exist between content knowledge as measured on the PRAXIS 2 exam and the content knowledge student teachers were required to demonstrate while completing their student teaching assignments. The decline in candidates' perceptions about knowledge of how children grow presents an additional concern that could be addressed through curricular or pedagogical program revisions. Both areas raise issues of review for this program, but do not appear related to the program's online delivery.

In areas of proficiency, such as classroom management, communicating well, and knowing how to teach, where modeling good practices are thought to be important and are often cited as reasons that online teacher preparation coursework may not be as effective as in person delivery, students perceived that the program prepared them better than they expected prior to student teaching. Upon completion of student teaching, candidates perceived that online course discussions, course assignments, instructor-to-student, and student-to-student interactions provided effective preparation for communicating well with students, peers, and the community. They reported that course assignments, instructor-to-student, and student-to-student interactions were effective preparation for managing a classroom and that course assignments and student-to-student interaction were effective preparation for knowing how to teach.

Prior to their student teaching experience, $75 \%$ of respondents said they were satisfied with the effectiveness of online resources provided via the courses, the overall online program, and the efficacy of their teaching skills. After student teaching, their satisfaction rate for these factors rose to $87.5 \%$. This rise in students' satisfaction of the program is significant, as student perceptions of efficacy and learning immediately following coursework, while useful indicators, may to some degree reflect positive experiences with instructors and peers as well as estimates of efficacy. Alternatively, post-student teaching perceptions are more likely to reflect how well the program actually prepared them for their classroom responsibilities, making the post-student-teaching satisfaction a more powerful indicator of program effectiveness than the 
pre-student-teaching data.

\section{Student Teaching}

Student teaching assessments also indicate the program's effectiveness at developing proficient candidates. During the semester of student teaching, candidates were observed by a university supervisor a minimum of three times and received a final evaluation within the last two weeks of student teaching. In addition, each candidate's cooperating teacher completed the same final evaluation form and was encouraged to make additional, more specific comments. The average student teaching score assigned by the university supervisors was 3.55 on a 4.0 scale, where 3 is satisfactory and 4 is exemplary. The average score was 3.50 for the cooperating teachers. Student teachers were rated using the 10 INTASC standards which include the dispositions, knowledge, and skills a beginning teacher is required to successfully demonstrate for licensure, such as subject matter knowledge, student learning and development, diverse learners, instructional strategies, motivational techniques, effective communication, instructional planning, formal and informal assessment, reflection on teaching, and collaboration. Comments made by the cooperating teacher revealed the value many of them placed on the experience and maturity the candidates brought to the classroom. One wrote:

Richard's content area knowledge is exemplary. Having been an archeologist, he brings an air of academic authority to the students. This is something that the students respond to and respect.

Another stated in her evaluation of a candidate seeking certification in business:

Because of Lauren's diverse business background, I feel that personally Lauren has a great deal to add to the curriculum she will be teaching.

Four of the candidates received comments related to the need to develop better lesson planning skills, and one cited classroom management as an area in need of improvement. Overall, however, comments were positive, with seven referring to the candidate as "a highly effective teacher." One wrote, "Julia was the best student teacher I have ever supervised." Additional comments cited the candidate's ability to relate well to the students (11); strong knowledge base in the content area (9); good lesson planning skills, including incorporating a variety of instructional strategies (9); well-developed technology skills (6); willingness to work hard (5); and a professional attitude.

\section{Interviews}

14 Schweizer, Hayslett, \& Chaplock 
Finally, 15 students agreed to participate in a phone interview conducted during the fall semester of the final year of the study. Interviewees were asked two questions:

- Why were you attracted to an online post baccalaureate certification program?

- Would you have applied if the program had NOT been completely online?

In response to the first question, eight themes emerged: flexibility and convenience, time for family, time for work, university's reputation, instructional format, distance from campus, price, and timing of degree completion. The second question revealed an interesting mix of responses and provided a more in-depth understanding of the motivational factors that influenced students' selection of an online program. Thirty-three percent of the students stated that they would not have applied to the program if it had not been online, 30\% responded that they definitely would have enrolled if it was offered face to face, and the remaining 37\% indicated they "probably would have enrolled," given certain conditions such as participation in the summer only. This tension between the students in our study wanting the convenience of a flexible online program and the willingness to enroll in a traditional face-to-face program if the online version was not available is evident when one student stated:

I was attracted to the online program because it met the flexibility needs that I have - with three children (one of whom is severely handicapped) anything I could do in my pj's late at night without worrying about upsetting carpools and babysitters was a HUGE plus.

In the next breath, the student stated,

I would have gotten my teaching license somehow, some way, even if it had meant that I had to do it face to face. I doubt that I would have been able to complete it as quickly though.

Another student explained,

As a working adult, I was looking for a program that fit into my schedule. An online program such as this one made the most sense to me and seemed doable in terms of my own life. I had investigated several options, including an evening program and a traditional face-to-face program. One was considerably more expensive and more drawn out, and the other required two semesters of student teaching.

And when prompted as to whether the student would have applied if the program had not 
been online, s/he responded,

I would have considered it if it were partially off-line, but since I live in another city I would have had considerable travel if the course work required me to be on campus. I would not have minded attending an occasional meeting with faculty if such meetings were scheduled well in advance. On the whole, though I am satisfied with the nature of the program.

The reputation of the university offering the online program weighed heavily with $33 \%$ of the respondents. One student stated:

I was also looking for a program from an institution that I admired and was well-known. Since I graduated from this university and was very happy with my undergraduate experience, I was naturally drawn back for this program.

Six of the interviewees made a direct reference to the "culture" of the online course, with one saying, "I bailed from another program when I realized that I would be with 24-year-old students. Not for me." And, another stated, "I like the idea of being able to study independently yet have an instructor and peers to whom I was accountable."

Reflecting the concerns of many adult learners, over half of the students reported that they benefited from the flexibility of the online learning environment where class attendance was regulated only by discussion and assignment deadlines every week, allowing them to work around commitments to jobs and family. Distance was also a factor for $40 \%$ of students who lived too far away, some out of state or several hours from campus, to attend a face-to-face program. Finally $40 \%$ of students reported that they appreciated that their online community of peers included more mature students, rather than being dominated by college-aged students. However, one student observed that being online has its limitations, lamenting that they "really didn't make colleagues or even friends. That was rough." Having a real world community where relationships foster such things as sharing war stories and advice appears to be limited online, at least for some, even within a cohort model. Achieving proficiency and excellence in teaching is a multifaceted process made even more complex when factoring in individual learner characteristics in an online environment. As one student wrote, "Online students have to be disciplined, dedicated, and tech savvy to succeed in this type of program." An online teacher certification program is not for everyone, but for those students needing a flexible delivery model that fits the busy lifestyle of a working adult and family member, it is an alternative to the traditional teacher preparation model.

\section{Principal's Evaluation}

16 Schweizer, Hayslett, \& Chaplock 
The post-induction year evaluation form, sent to principals of schools where program graduates completed their first year of teaching, consisted of 19 indicators, again aligned with the Wisconsin Teaching Standards. As of this writing, three students have completed their first year teaching. The evaluations for all three were returned rating the first year teachers 3.1, 3.1, and 3.4 on a scale from 1-4, with 3 representing satisfactory and 4 representing exemplary performance. Comments from principals hiring graduates of this online program expressed satisfaction with the performance of these teachers after their induction year. Personal characteristics cited include being "accountable, prompt, and responsible." Beyond this, and judged by principals to be even more important, was the relationship between the teachers and their students, with one principal noting a teacher was "very well liked and respected by her students." Principals expressed satisfaction with the new teachers and commented that they felt fortunate to have them. Specific references to "complete command" of content knowledge, and ability to deal "very well with "at risk' students" provided enthusiastic support and appreciation for the knowledge and abilities these new teachers brought to their schools and mirrors the comments made by cooperating teachers.

\section{Discussion}

This study demonstrates the effectiveness of this online teacher certification program, thereby supporting the contention that such a program is viable, although additional research is warranted. Scores on coursework, student teaching assessments, and available principal evaluations all confirm that the online program prepared students to teach in secondary classrooms. Rigorous admission standards refined the pool of candidates to those who were likely to successfully complete program requirements. Further, the median age of students was 37.6. Older learners benefit from maturity and life experiences that inform their studies and practice. These candidates were highly motivated to change careers and made sacrifices that most college-aged students rarely face, including accommodating coursework while fully employed and bearing the additional expense of tuition while supporting their families.

However, a high level of motivation cannot always overcome the complicated lifestyles of working adults and caregivers. The disappointing $42 \%$ dropout rate, in which seven men and seven women left the program, raises concerns. Job and family conflicts, mentioned in formal interviews and disclosed in informal emails and phone conversations with instructors, were often cited as reasons for dropping the program. In particular, some students found it too difficult to complete the required 100 observation hours while working 40 hours a week, or impossible to 
financially manage an unpaid semester of student teaching. Alternatives to clinical hours and the required, unpaid semester warrant exploring. One option could be paid internships, with intensive mentoring and supervision. Finally, the data on program dropouts also reveal a tendency for students living closest to the university (within 15 miles of campus) to be more apt to complete the program than those living outside the state or the country. Specifically, $100 \%$ (three) of the students living in other states or another country and 43\% (six) of those living 15 miles or more from campus failed to complete certification. Although distance does not appear to be the underlying reason for those outside the state leaving the program, as they cited personal and job-related reasons, additional information is needed to explore whether the availability of face-to-face contact and/or support, quality of instruction, or program characteristics and structure may still be contributing factors. Reconceptualizing program attrition as a reflection of the many aspects of people's complex lives in light of program requirements and constraints, rather than merely an indicator of "academic non-success," may clarify the way in which students can be better served and less likely to choose to leave the program. Video conferencing, synchronous faculty office hours, and a course "concierge" assigned to create campus connections and assist students in managing the academic aspect of students' lives may be useful supports to all students participating in online certification programs, but they may be particularly useful in providing bridges should geographical gaps or circumstantial conflicts be contributing factors to attrition.

Finally, the students are discerning "buyers" and reported that the university's quality and reputation were important in the final selection of their program. These factors weighed in heavily when considering how high the stakes are for these students. They are risking time, money, and a career change. It is in their best interest to succeed in a well-respected program.

The eight themes identified in the interview (flexibility and convenience, time for family, time for work, university's reputation, instructional format, distance from campus, price, and timing of degree completion) are consistent with the research on why students enroll in online courses (Sloan, 2005). When considering the need to attract highly qualified teachers, specifically in the areas of science and math, the flexibility and convenience of an online program offered by a reputable institution appears to provide the incentive for career changers to take the leap, but the exodus of those pursuing math credentials creates concern. The compressed nature of the course of study-most students were able to complete the online program within five semesters - creating time- and labor-intensity for some students was also a factor. For some, maintaining the financial security of a job while preparing for a new career provided many of the 
students in our study the opportunity to explore the teaching profession in a relatively low-risk fashion.

Online teacher certification programs may serve an important purpose in light of larger teacher preparation issues. Far-reaching reform efforts that mandate the hiring of more qualified teachers are forcing institutions of higher education to take a hard look at licensing standards. In particular, there is a growing problem of the least prepared teachers concentrated in schools with the greatest learning needs and challenges (Hunt \& Carroll, 2003). At the same time, teacher shortages, particularly in math and science, are reaching crises levels. Estimates in high-poverty urban and rural districts place the demand for new teachers in the range of 700,000 (Ingersoll, 2003). Additionally, higher rates of teacher turnover occur in districts where students come from high-poverty homes (Ingersoll, 2003). And, according to Herrington (2006), "teacher shortages will be found in the teaching fields of bilingual education, special education, mathematics, science, and foreign languages." This enormous demand for new teachers has created a need to extend teacher certification and post-baccalaureate degree programs to a larger audience. Providing a flexible and convenient online delivery system that better meets the needs of adult learners often over-burdened with job and family responsibilities is one way to begin to expand the pool of potential future teachers.

While the program attracted participants from urban and rural settings with a wide age range (21-54), it was not as successful in recruiting and retaining students of color. Recruitment efforts included editorial pieces in local newspapers, radio announcements, on campus information sessions, a commercial online higher education recruiting site, and a featured announcement page on the University's School of Education website. Most students who enrolled found the program through Web-based sources. With the number of Web sites targeting minority users on the rise since the inception of this program, we might have better success now using the Web to recruit more diverse participants. Our expectation that we would recruit significant numbers of teachers on emergency licenses from local area urban schools was not realized. Most of area teachers are already licensed or are in certification programs sponsored by their district or an area education agency. We also surmise that our experience is in keeping with the research of Gordon (2002) and King (1993) that students of color with bachelor's degrees are highly sought after and can earn more in fields they perceive to have greater prestige. The one African-American student in the program expressed her desire to leave a corporate career because she felt a calling to teach and a desire to give back to her community. Her motivation is consistent with research that suggests that minority teachers serve as important role models for 
students and help to build bridges between minority and dominant cultures within the school environment. More important, they serve as examples of successful, respected professionals in the community, and reinforce our contention that racial diversity is an important goal for this online certification program (Gordon, 2002; Cavallo, Ferreira, \& Roberts, 2005).

This study clearly supports online delivery as an effective means of teacher preparation, but it was limited in the number of students followed into their first year of teaching. As of this writing, only three students have completed their first year of teaching. A longitudinal study that monitors teaching performance throughout the first five years would yield important information related to both teaching efficacy and retention. Also, gathering more detailed data on student expectations upon entry and reasons for leaving the program early would better inform program revisions and enhancements. Addressing these limitations is but one line of potential further research. This study also suggests several other areas for additional exploration. For instance, given the continuing demand for teachers in high-need subject areas and the number of students seeking math and science certification leaving this program early, further research might shed light on the appropriateness of online delivery for certification in particular subject areas. Additionally, the program in this study (like most online certification programs) offers only secondary certification; further research is needed to examine the viability of offering K-8 and multiple subject certification programs online. Finally, additional study is warranted investigating the relationship between student characteristics and program completion.

Exploring whether some people are more likely than others to leave online programs before completion, as well as to better understand how particular people may be better served by online certification programs, deserves attention.

The online post baccalaureate certification program described in this study provides an avenue to teaching for those who need or prefer the convenience and flexibility of online education, particularly nontraditional students. They bring to the profession life and job-related experiences (naval pilot, archeologist, author, army officer, for example) that provide students the real world connections needed to make largely abstract subject matter meaningful. Enabling these individuals to seek licensure online when on-campus programs provide notable, sometime insurmountable, obstacles may go a long way toward providing the kind of highly qualified teachers needed in many classrooms.

\section{Notes}

Heidi Schweizer is an associate professor in the College of Education, Educational Policy 20 Schweizer, Hayslett, \& Chaplock 
and Leadership Department, at Marquette University, where Carrianne Hayslett recently received a Ph.D. and Sharon Chaplock is a doctoral student.

\section{References}

Arbaugh, J. B. (2000). Virtual classroom versus physical classroom: An exploratory comparison of class discussion patterns and student learning in an asynchronous Internet-based MBA course. Journal of Management Education, 24(2), 207-277.

Bean, J. P., \& Metzner, B. S. (1985). A conceptual model of nontraditional undergraduate student attrition. Review of Educational Research, 55, 485-540.

Boyles, L.W. (2000). Exploration of a Retention Model for Community College Student. University of North Carolina at Greensboro: Unpublished Doctoral Dissertation

Carnevale, D. (2003, March 11). Western Governors U opens a new online college for teachers. The Chronicle of Higher Education.

Carr, S. (2000). As distance education comes of age, the challenge is keeping the students. The Chronicle of Higher Education, 46(230), A39.

Cavallo, A., Ferreira, M., \& Roberts, S. (2005). Increasing student access to qualified science and mathematics teachers through an urban school-university partnership. School Science and Mathematics, 105(7), 363-372.

Caywood, K., \& Duckett, J. (2003). Online vs. on-campus learning in teacher education. Teacher Education and Special Education, 26(2), 98-105.

Council of Chief State School Officers. (2006). INTASC portfolio development. Retrieved July 26, 2006, from http://www.ccsso.org/projects/Interstate_New_Teacher_Assessment_and_Support_Con sortium/Projects/Portfolio_Development.

Darling-Hammond, L. (2007). We need to invest in math and science teachers. The Chronicle of Higher Education, 54(17), B20.

Diaz, D. P. (2002). Online drop rates revisited. The Technology Source, May/June 2002. Accessed January 28, 2006, at http://technologysource.org/article/online_drop_rates_revisited/

Flood, J. (2002) Read all about it: online learning facing $80 \%$ attrition rates. The Turkish Online Jouurnal of Distance Education, 3, 2. Accessed January 28, 2008, at http://tojde.anadolu.edu.tr/tojde6/articles/jim2.htm

Glenn, J., \& Lozar, M. (2001). Supporting teacher learning: Professional development goes

21 Schweizer, Hayslett, \& Chaplock 
online. Business Education Forum, 56(2), 8-13.

Gordon, J. (2002). The color of teaching. UK: Routledge.

Herrington, D., Salinas, R., \& Kritsonis, W. (2006). Teacher quality as a predictor of student achievement in urban schools: A national focus. The Lamar University Electronic Journal of Student Research, 3(Spring).

Howard, P.N., \& Jones, S. (2004). Society Online: The Internet in Context. Thousand Oaks: Sage.

Hunt, J. B., \& Carroll, T. G. (2003). No dream denied: A pledge to America's children. Washington, DC: National Commission on Teaching and America's Future. Retrieved April 16, 2006, from http://www.nctaf.org/documents/nctaf/report.pdf.

Ingersoll, R. (2003). Is there really a teacher shortage? A research report co-sponsored by Center for the Study of Teaching and Policy and The Consortium for Policy Research in Education. Seattle, Washington: Center for the Study of Teaching and Policy.

Institute for Higher Education Policy. (1999). What's the difference? A review of contemporary research on the effectiveness of distance learning in higher education. Retrieved July 26 , 2006, from http://www.ihep.com/Pubs/PDF/Difference.pdf.

Interstate New Teacher Assessment and Support Consortium (INSTASC) (1992). Model standards for beginning teacher licensing, assessment and development: a resource for state dialogue. Retrieved July 26, 2006, from http://www.ccsso.org/content/pdfs/corestrd.pdf.

Johnson, B., \& Christensen, L. (2004). Educational research: Quantitative, qualitative, and mixed approaches. $\left(2^{\text {nd }}\right.$ ed). Boston: Allyn and Bacon.

Kember, D. (1989). A Longitudinal-Process Model of Drop-Out from Distance Education. Journal of Higher Education, 60(3), 278-301

King, S. (1993). Why did we choose teaching careers and what will enable us to stay? Insights from one cohort of the African-American teaching pool. The Journal of Negro Education, 62(4), 475-492.

McCubbin, I. (2003). An Examination of Criticisms made of Tinto's 1975 Student Integration Model of Attrition. Retrieved January 29, 2008, from http://www.psy.gla.ac.uk/ steve/localed/icubb.pdf.

Meyer, K.A., Bruwelheidi, J., \& Poulin, R. (2006). Why they stayed: near-perfect retention in an online certification program in library media. Journal of Asynchronous Learning Networks, 10(4).

22 Schweizer, Hayslett, \& Chaplock 
National Center for Educational Statistics (NCES). (1999). 1997-1998 Postsecondary Schools Report. Retrieved July 26, 2006, from http://nces.ed.gov/pubs2000/2000013.pdf.

Neuhauser, C. (2002). Learning style and effectiveness of online and face-to-face instruction. American Journal of Distance Education, 16(2), 99-113.

Philadelphia Citizens for Children and Youth \& The Alliance Organizing Project. (2001). Who Will Teach Our Children? Philadelphia: Author

Poirier, C., R. \& Feldman, R. S. (2004). Teaching in Cyberspace: Online versus traditional instruction using a waiting-list experimental design. Teaching of Psychology, 31(1), 59-62.

Qian, G. \& Tao, L. (2005). In-service teachers and computer mediated discussions: Ranges and purposes of reflection. Reading Horizons, 46(2), 115-142.

Rovai, A. P. (2002). Development of an instrument to measure classroom community. Internet and Higher Education, 5(3), 197-211.

Russell, T.L. (2001). The no significant difference phenomenon: A comparative research annotated bibliography on technology for distance education. Montgomery, AL: IDECC.

Saunders, E. A. (2001). Interactive online learning for teachers. NASSP Bulletin, 85(628), 51-57.

Shen, J. (1999). Alternative certification: math and science teachers. Educational Horizons, $78(1)$.

Simmons, S. C. \& Mebane, D. J. ( 2005). NC TEACH and NC TEACH OnLine: Viable alternative routes to teaching in North Carolina. Action in Teacher Education, 27(1), 45-52

Skylar, A. A., Higgins, K., Boone, R. \& Jones, P. (2005). Distance education: an exploration of alternative methods and types of instructional media in teacher education. Journal of Special Education Technology, 20(3), 25-34.

Sloan Consortium. (2006). Making the grade: Online education in the United States, 2006. Retrieved November 14, 2006, from http://www.sloan-c.org/publications/survey/index.asp.

Spooner, T., \& Rainie, L. (2000). African Americans and the Internet. Washington D.C.: Pew Online Life Project.

Steinweg, S.B., Davis, M.L., \& Thomson, W.S. (2005). A comparison of traditional and online instruction in an introduction to special education course. Teacher Education and Special Education, 28(1), 62-73.

23 Schweizer, Hayslett, \& Chaplock 
Thirunarayanan, M.O., \& Perez-Prado, A. (2002). Comparing web-based and classroom-based learning: A quantitative study. Journal of Research on Technology in Education, 34(2), 131-8.

Tinto, V. (1975). Dropout from higher education: A theoretical synthesis of recent research. Review of Educational Research, 45, 89-127.

Tinto, V. (1987). Leaving college: Rethinking the causes and cures of student attrition. Chicago: University of Chicago Press.

Turbill, J. (2001). A face-to-face graduate class goes online: Challenges and successes. Reading Online, 5(1). Retrieved September 20, 2006 from http://www.readingonline.org/international/inter_index.asp?HREF=/international/turbill1/i ndex.html.

Tyler-Smith, K. (2006). Early attrition among first time elearners: a review of factors that contribute to drop-out, withdrawal an non-completion rates of adult learners undertaking elearning programmes. Journal of Online Learning and Teaching, 2(2), 73-85.

U. S. Department of Commerce. (2000). Falling through the net: Toward digital inclusion.

Retrieved July 26, from The Economics and Statistics Administration, U.S. Department of Commerce Web site: http://www.esa.doc.gov/fttn00.pdf.

U. S. Department of Education. (2005). Preparing tomorrow's teachers to use technology program (PT3). Retrieved July 26, 2006 from www.readingonline.org/international/inter_index.asp?HREF=turbill1/index.html.

U. S. Department of Education. (2003). Teachers' College Western Governors University. The Education Innovator \#1. Retrieved July 26, 2006 from http://www.ed.gov/news/newsletters/innovator/2003/0306.html.

Watson, G. (2006). Technology professional development: Long-term effects on teacher self-efficacy. Journal of Technology and Teacher Education, 14(1), 151-166.

Wisconsin Department of Public Instruction. (2006). Wisconsin Educator Development and Licensure Standards. Retrieved August 1, 2006 from http://dpi.wi.gov/tepdl/standards.html

Zirkle, C. (2002). Distance education and the trade and industry educator. Tech Directions, 62(4), 32-37.

\section{Appendix}

Table 1

Pre-program and post-program student teaching survey results $(\mathrm{N}=8)$

24 Schweizer, Hayslett, \& Chaplock 


\begin{tabular}{|l|c|c|c|c|c|c|c|c|c|c|}
\hline $\begin{array}{l}\text { Wisconsin Teaching } \\
\text { Standards }\end{array}$ & \multicolumn{2}{|c|}{$\begin{array}{c}\text { Course } \\
\text { Material }\end{array}$} & \multicolumn{2}{|c|}{$\begin{array}{c}\text { Course } \\
\text { Discussions }\end{array}$} & \multicolumn{2}{c|}{$\begin{array}{c}\text { Course } \\
\text { Assignments }\end{array}$} & \multicolumn{2}{|c|}{$\begin{array}{c}\text { Instructor-to- } \\
\text { student } \\
\text { interaction }\end{array}$} & $\begin{array}{c}\text { Student-to- } \\
\text { student } \\
\text { interaction }\end{array}$ \\
\hline & Pre & Post & Pre & Post & Pre & Post & Pre & Post & Pre & Post \\
\hline $\begin{array}{l}\text { Know the subject you are } \\
\text { teaching }\end{array}$ & 3.8 & 2.8 & 4.1 & 2.6 & 4.1 & 2.4 & 3.8 & 2.6 & 3.8 & 2.9 \\
\hline Know how children grow & 4.3 & 4.0 & 4.4 & 3.8 & 4.0 & 3.9 & 4.0 & 3.9 & 3.9 & 3.5 \\
\hline $\begin{array}{l}\text { Understand that children } \\
\text { learn differently }\end{array}$ & 4.6 & 4.8 & 4.3 & 4.4 & 4.3 & 4.4 & 4.3 & 4.0 & 4.3 & 4.3 \\
\hline Know how to teach & 4.0 & 3.9 & 4.3 & 4.1 & 4.0 & 4.1 & 4.0 & 3.9 & 3.9 & 4.1 \\
\hline $\begin{array}{l}\text { Know how to manage a } \\
\text { classroom }\end{array}$ & 4.3 & 3.8 & 3.6 & 3.6 & 3.5 & 3.6 & 3.5 & 3.8 & 3.9 & 3.8 \\
\hline Communicate well & 3.9 & 3.6 & 4.0 & 4.4 & 4.1 & 4.3 & 3.9 & 4.4 & 3.8 & 4.3 \\
\hline $\begin{array}{l}\text { Plan different kinds of } \\
\text { lessons }\end{array}$ & 4.0 & 4.6 & 4.1 & 4.1 & 4.0 & 4.6 & 3.8 & 4.1 & 4.1 & 4.3 \\
\hline Test for student progress & 3.8 & 4.0 & 3.8 & 3.7 & 4.0 & 3.7 & 3.9 & 3.4 & 3.6 & 3.7 \\
\hline $\begin{array}{l}\text { Evaluate yourself as a } \\
\text { teacher }\end{array}$ & 3.9 & 3.8 & 3.8 & 4.3 & 3.9 & 4.1 & 4.3 & 4.3 & 3.8 & 4.4 \\
\hline $\begin{array}{l}\text { Connect with other } \\
\text { teachers in the community }\end{array}$ & 3.4 & 3.1 & 3.4 & 2.4 & 3.4 & 3.4 & 2.6 & 3.5 & 3.8 & 3.9 \\
\hline
\end{tabular}

Note: Scale $=1$ (not at all) -5 (very much) 